\title{
Immune Basis of Allergic Reactions to Food
}

\author{
Lozano-Ojalvo $\mathrm{D}^{1}$, Berin $\mathrm{C}^{1 *}$, Tordesillas $\mathrm{L}^{2 *}$ \\ 'Jaffe Food Allergy Institute, Immunology Institute, Mindich Child Health Institute, Icahn School of Medicine at Mount Sinai, New York, New \\ York, USA \\ ${ }^{2}$ Department of Tumor Biology, H. Lee Moffitt Cancer Center, Tampa, Florida, USA \\ *Both authors contributed equally to the manuscript.
}

J Investig Allergol Clin Immunol 2019; Vol. 29(1): 1-14

doi: 10.18176/jiaci.0355

\section{Abstract}

Food allergies are diseases where the normal tolerance response to oral antigens is altered. Recent advances have begun to uncover mechanisms that mediate sensitization to food allergens and maintenance of the disease. Production of alarmins by epithelial cells triggers a cascade that leads to allergen-specific IgE synthesis. IL-9 has also been shown to play a role in mast cell recruitment and amplification of the allergic response. In recent years, increasing evidence suggests that sensitization to food allergens can be developed via nonoral routes, in particular the skin, thus leading to the "dual exposure hypothesis". Environmental factors such as diet or microbiota can shape the immune system to promote tolerance or sensitization to food antigens. While the mechanism of primary tolerance to food antigens is quite clear, that leading to permanent tolerance in food-allergic individuals through immunotherapy is still under study. Understanding the mechanisms by which oral tolerance is suppressed and sensitization develops will help to identify new targets to develop combined therapies for the treatment of food allergies.

Key words: Food allergy. Skin sensitization. Oral tolerance. Microbiota. Allergen-specific immunotherapy.

\section{Resumen}

La alergia alimentaria es una enfermedad en la que la respuesta fisiológica normal de tolerancia a los antígenos orales se encuentra alterada. Los nuevos avances en la investigación han comenzado a desvelar los mecanismos que median tanto en la sensibilización a los alérgenos alimentarios como en la persistencia de la enfermedad. La producción de alarminas por parte de las células epiteliales desencadena una cascada que conduce a la síntesis de lgE específica frente a los alérgenos alimentarios. También se ha identificado el papel de la IL-9 en el reclutamiento de mastocitos y la amplificación de la respuesta alérgica. Además en estos últimos años se han completado diversas investigaciones que sugieren que la sensibilización a los alérgenos alimentarios puede desarrollarse por vías no orales, en particular a través de la piel, lo cual ha llevado a la propuesta de la denominada "hipótesis de la doble exposición". Por último, factores ambientales como la dieta o la microbiota pueden moldear el sistema inmunológico para promover la tolerancia o la sensibilización a los antígenos alimentarios. Si bien el mecanismo de tolerancia primaria a los antígenos alimentarios es bastante claro, el que conduce a la tolerancia permanente en individuos que ya tienen alergia a los alimentos a través de la inmunoterapia aún está en estudio. Comprender los mecanismos mediante los cuales se suprime la tolerancia oral y se desarrolla la sensibilización ayudará a identificar nuevos objetivos para desarrollar terapias combinadas para el tratamiento de alergias alimentarias.

Palabras clave: Alergia alimentaria. Sensibilización cutánea. Tolerancia oral. Microbiota. Inmunoterapia específica con alérgenos. 


\section{Introduction}

Food allergies are the result of an altered response to dietary antigens; however, the mechanism that leads to this altered response is not yet clear. Alterations in the gastrointestinal epithelium and presence of adjuvant activity such as that of bacterial toxins have been shown to break the normal tolerance response to food antigens and promote food allergy in experimental models. However, in recent years, increasing evidence suggests that sensitization to food allergens can develop through nonoral routes, in particular the skin. Here, we review recent advances in our understanding of the mechanism of sensitization to food allergens, as well as environmental factors that modify immune responses to promote tolerance or food allergy. We also discuss whether it is possible to permanently modify pre-existing allergic responses to induce tolerance to foods.

\section{Reprogramming of Oral Tolerance Towards Sensitization}

The normal response to oral antigens is that of oral tolerance, which is defined as active suppression of antigenspecific immune responses induced in the gastrointestinal tract. Oral tolerance is initiated by $\mathrm{CD}_{103^{+}}$dendritic cells (DCs), which capture antigen in the lamina propria and migrate to the mesenteric lymph nodes. In response to antigen presentation by $\mathrm{CD}_{103}{ }^{+} \mathrm{DCs}$, naïve $\mathrm{T}$ cells differentiate to regulatory $\mathrm{T}$ cells (Tregs) through a mechanism dependent on TGF- $\beta$ and retinoic acid [1-3]. Retinoic acid is required to induce expression of the gut-homing markers CCR 9 and $\alpha 4 \beta 7$ by T cells [4]. Antigenspecific Tregs expressing gut homing markers migrate from the lymph nodes to the lamina propria, where they expand in response to IL-10 production by $\mathrm{CX} 3 \mathrm{CR} 1^{+}$macrophages [5]. Oral tolerance to food antigens requires induction of Tregs, as ablation of Foxp $3^{+}$Tregs has been shown to result in loss of oral tolerance [5]. In addition, mutations in the Foxp3 locus, a transcription factor that is essential for Treg development, are associated with development of severe food allergy [6].

Factors that increase antigen delivery to tolerogenic $\mathrm{CD}_{103}{ }^{+} \mathrm{DCs}$ favor the induction of Tregs, such as formation of goblet cell-associated antigen passages (GAPs) in the intestinal epithelium that deliver antigen exclusively to CD $103{ }^{+} \mathrm{CXC}_{3} \mathrm{CR} 1^{-}$DCs [7]. Production of mucin by goblet cells increases the frequency of GAPs, thus enhancing antigen delivery [7]. In addition, hyperglycosylated mucin MUC2 imprints $\mathrm{CD} 103^{+}$DCs with a regulatory phenotype through the induction of TGF- $\beta$, RALDH, IL-10 expression, and suppression of inflammatory cytokines, thus promoting oral tolerance [8]. Microbial signals, sensed by intestinal macrophages, also regulate the phenotype of $\mathrm{CD}_{103^{+}} \mathrm{DCs}$. In response to these microbial signals, macrophages induce production of granulocyte-macrophage colony-stimulating factor (GM-CSF) by innate lymphoid cell (ILC) 3, which acts on DCs and macrophages and promotes accumulation of Tregs and intestinal homeostasis [9].

Several studies support the tolerogenic nature of oral exposure. Early consumption of food, such as peanuts, fish and wheat, has been associated with a reduced incidence of food allergy [10-12]. In a trial to determine the effect of early introduction of peanuts in children with a high risk for development of peanut allergy, early consumption was associated with a dramatic decrease in the frequency of allergy to this food, which was maintained over time, even with the interruption of peanut consumption for 12 months [13]. Additional trials performed to extend findings to the general population $[14,15]$ and to study the effect of early introduction of other foods such as egg have yielded different results [16-18]. A meta-analysis of randomized controlled trials concluded that early introduction of egg or peanut to the diet was moderately associated with a lower risk of developing allergies to these foods [19].

During development of food allergy, the normal oral tolerance response to dietary proteins is altered and there is a deviation of T-cell responses towards a $\mathrm{T}_{\mathrm{H}} 2$ phenotype characterized by IL-4 production. IL-4 production is required for B-cell class-switching and synthesis of antigen-specific IgE. Although IL-4 has usually been associated with $\mathrm{T}_{\mathrm{H}} 2$ responses, IL-4 can also be produced by $\mathrm{T}$ follicular helper cells (Tfh). Tfh are required for germinal center development and function and induce B-cell class switching [20]. A recent paper using a model of peanut allergy by airway exposure shows that $\mathrm{Tfh}$, defined as $\mathrm{ST} 2{ }^{-} \mathrm{CXCR} 5^{+}$, are required for $\mathrm{IgE}$ antibody production and development of peanut allergy [21]. By contrast, a model of skin exposure to crude peanut extract showed that there was no induction of $\mathrm{CXCR}^{+} \mathrm{ICOS}^{+} \mathrm{Tfh}$ in the draining lymph nodes [22]. Thus, the role of $\mathrm{Tfh}$ responses in the development of food allergy needs to be further elucidated.

In mouse models, the default response to antigens via the oral route is immune tolerance. Therefore, to mimic food allergic sensitization in mouse models, it is necessary to break the oral tolerance response by the use of adjuvants. These adjuvants promote $\mathrm{DC}$ maturation, $\mathrm{T}_{\mathrm{H}} 2$ skewing, and IgE production.

Cholera toxin (CT) has been widely used to sensitize to antigens through the oral route $[23,24]$. Oral administration of CT induces increased migration of CD103+ DCs and upregulation of OX40L, which mediates $\mathrm{T}_{\mathrm{H}} 2$ skewing of naïve T cells $[25,26]$. Upregulation of OX40L on DCs was found to be dependent on IL-33 production by gastrointestinal epithelial cells in response to CT but independent of IL-25 and thymic stromal lymphopoietin (TSLP) [26]. In addition, eosinophils can also contribute to activation and migration of DCs by releasing eosinophil-specific granule protein (EPO) in response to peanut and CT [27]. EPO acts as an adjuvant, inducing maturation of $\mathrm{CD} 103^{+} \mathrm{DCs}$ and promoting allergic sensitization. Uric acid, an alarmin that is released after cellular damage, is also elevated in response to antigen feeding and $\mathrm{CT}$ and presents adjuvant activity [28]. Induction of $\mathrm{T}_{\mathrm{H}} 2$ responses to food antigens in the presence of CT is associated with suppression of antigen-specific Tregs in the gastrointestinal tract [29]. Figure 1 summarizes the different mechanisms implicated in the development of sensitization to food allergens.

Although the use of CT to sensitize through the oral route has been extensively used, CT is unlikely to be relevant 


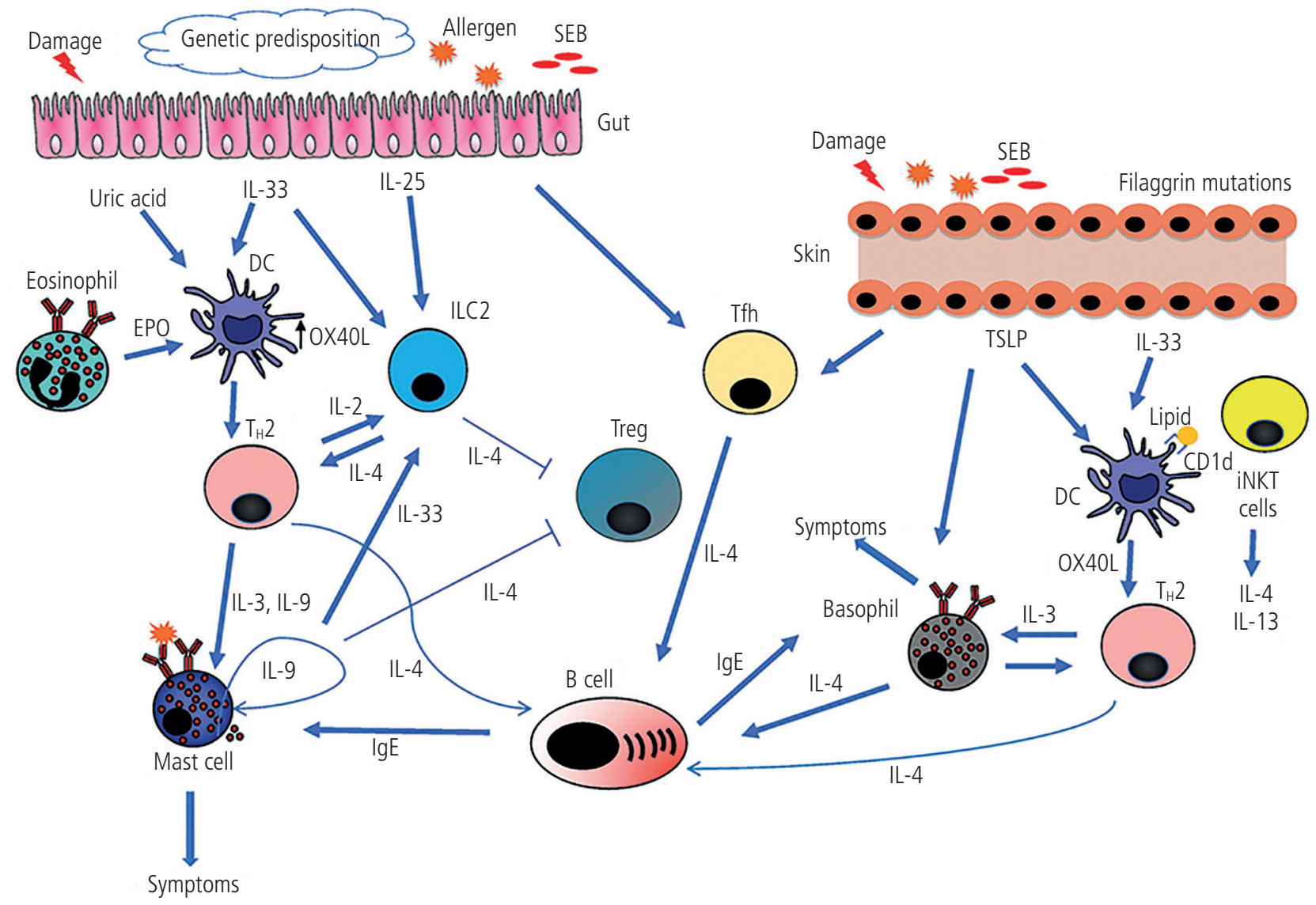

Figure 1. Mechanism of sensitization to food allergens. Food allergens in the presence of adjuvants (eg, bacterial toxins), epithelial damage, and genetic factors promote the induction of epithelial cytokines in the gut that act as alarmins inducing DC maturation. DCs present antigens to T cells, inducing $T_{H} 2$ responses. EPO produced by eosinophils can also act as alarmin. $T_{H} 2$ cells produce IL-4, which promotes lgE class-switching on B cells and suppression of Tregs. Tfh can also contribute to B-cell class switching and IgE production. TH2 cells produce IL-3 and IL-9, which act on mast cells and amplify allergic responses. IL-33 and IL-25 can also act on ILC2, thus contributing to suppression of Tregs. Similar mechanisms have been described in the skin. Basophils have also been shown to promote $T_{H} 2$ responses in mouse models. Presentation of lipid carried by antigens to iNKT cells can also act as an immunomodulator and may play a role in inducing sensitization to food antigens. DC indicates dendritic cell. EPO, eosinophilic granule protein; SEB, staphylococcal enterotoxin B; TSLP, thymic stromal lymphopoietin.

for allergic sensitization in humans. By contrast, the use of staphylococcal enterotoxin B (SEB) as an adjuvant may be more relevant in sensitization to food allergens. SEB is a toxin produced by Staphylococcus aureus, which colonizes $90 \%$ of patients with atopic dermatitis [30]. Oral exposure to SEB promoted maturation of intestinal DCs and enhanced expression of TIM-4, which was required to induce $\mathrm{T}_{\mathrm{H}} 2$ polarization in vivo [31]. Mice that were sensitized to ovalbumin (OVA) in the presence of SEB presented reduced levels of TGF- $\beta$ expression by splenocytes restimulated with antigen in vitro, suggesting that, similar to CT, SEB mediated suppression of oral tolerance by impairing induction of Tregs [32].

Other models to study allergic sensitization through the oral route are those modeling genetic susceptibility. An example is the mouse model carrying a gain-of-function mutation at position 709 of the IL-4R $\alpha$ chain (IL4raF709 mouse), which inactivates the immunoreceptor tyrosine-based inhibitory motif [33]. Polymorphisms in the IL-4/IL-13 axis are associated with atopy [34] and, likewise, IL4ra709 mice are prone to develop food allergy by oral sensitization, even in the absence of an external adjuvant. Similar to the models using adjuvants, development of food allergy to oral antigen in this model is associated with defective induction of allergen-specific Tregs in the gastrointestinal tract [35]. Production of IL-4 by mast cells in response to oral antigen suppresses induction of Tregs and promotes reprogramming of Treg cells into a $\mathrm{T}_{\mathrm{H}} 2$ pathogenic phenotype [36]. ILC2 can also produce high levels of IL-4, which contribute to reprogramming of Tregs [37]. These pathogenic Tregs express IL-4 and GATA-3, while retaining Foxp3 expression, and are defective in suppressing food allergy. Moreover, peripheral blood mononuclear cells (PBMCs) from milk-allergic children have increased IL-4 and IL-13 expression by milk-specific Tregs after re-stimulation with milk compared with PBMCs from healthy controls or from peanut-allergic individuals without milk allergy [36], suggesting that reprogramming of Tregs to $\mathrm{T}_{\mathrm{H}} 2$ is also present in food-allergic humans. The mouse models of experimental 
allergy described above suggest that a functional antigenspecific population of Tregs is required to induce oral tolerance to foods and that exogenous factors that alter the normal tolerant environment of the gut and genetic predisposition may lead to impairment of Treg function and $\mathrm{T}_{\mathrm{H}} 2$ skewing in the gastrointestinal tract. The role of Tregs in the development of tolerance to foods in humans is further supported by a study showing that children who have naturally outgrown food allergy present higher numbers of antigen-responsive Foxp $3^{+}$ Tregs and IL-10-expressing CD4 $4^{+} \mathrm{T}$ cells than children with active food allergy or nonallergic controls $[38,39]$. By contrast, no peanut-specific Tregs were found in PBMCs from children with a history of peanut allergy who tolerated a cumulative dose of $1 \mathrm{~g}$ of peanut and healthy controls after stimulation with peanut, suggesting that naturally occurring tolerance may also be mediated by immunologic ignorance or anergy [40]. Induction of IgG antibodies, especially IgG4, has also been associated with development of primary oral tolerance to foods [16,41]. IgGs can act as blocking antibodies, inhibiting the binding of $\operatorname{IgE}$ to the allergen [42], and are able suppress development of $\operatorname{IgE}$ and anaphylaxis by acting through the inhibitory receptor Fc $\gamma$ RIIb [43]. In addition, the presence of IgG-allergen immune complexes has been associated with the development of tolerance to OVA in offspring from OVAsensitized mice. These immune complexes were transferred by breastfeeding and detected by neonatal $\mathrm{Fc}$ receptors present in DCs and promoted the generation of Tregs [44]. Thus, IgG antibodies have a role in reinforcing the regulatory response to food antigens.

\section{Role of Mast Cells and IL-9}

Mast cells are main players in the effector phase of IgEmediated food allergy. Degranulation of mast cells due to cross-linking of antigen-specific IgE bound to high-affinity FceRI induces the release of preformed and newly synthesized mediators that are responsible for allergic symptoms. Mast cell subsets are implicated in various manifestations of food allergy in mice. While connective tissue mast cells are associated with systemic anaphylaxis, both connective tissue and mucosal mast cells are involved in gastrointestinal manifestations [45]. However, mast cells are not only implicated in the effector phase, but also play a key role in sensitization to food allergens. They produce cytokines such as IL-4 and IL-9, which promote $\mathrm{T}_{\mathrm{H}} 2$ responses and IgE production and suppress Treg responses $[35,46]$. IL-9 is a mast cell growth factor that has a pivotal role in promoting intestinal mastocytosis and food-induced anaphylaxis $[47,48]$. A population of mast cells producing high amounts of IL-9 and IL-13 was identified in response to repeated intragastric challenge [46]. These IL-9producing mast cells (MMC9) were induced by $\mathrm{T}_{\mathrm{H}} 2$ cells, and their depletion suppressed the development of intestinal mastocytosis and food allergy, while transfer of MMC9s restored allergic responses. The role of IL-9 in food allergy was further supported by the finding that expression of IL9 gene transcript in the duodenum of food-allergic patients was upregulated in comparison with controls [46]. Moreover, T cells from food-allergic patients that were stimulated with the offending allergen presented higher IL-9 expression than $\mathrm{T}$ cells from controls, suggesting that IL-9 is a good marker for differentiating between allergic and nonallergic patients $[40,49,50]$. Mast cells can produce IL-9 in response to the alarmin IL-33, which increases IgE-mediated degranulation and cytokine production and is critical for the induction of food anaphylaxis after oral challenge [46,51]. Mast cells can also drive expansion of ILC2, by production of IL-33 and IL-4, which further amplifies the severity of IgE-mediated anaphylaxis $[37,52,53]$.

\section{Sensitization to Food Allergens Through Nonoral Routes}

The oral route was traditionally thought to be the main route for sensitization to food allergens. However, in most cases, children experience their first allergic reaction to peanuts on their first known ingestion [54], suggesting that sensitization can occur through nonoral routes or during pregnancy.

Sensitization to food allergens in utero has been studied by analyzing allergen-specific IgE levels from cord blood and newborn blood [55]. Nevertheless, the impact of maternal diet on sensitization remains unclear. Some studies suggest that maternal consumption of peanuts during pregnancy could be a risk factor for development of peanut sensitization [56], while other studies found no evidence of prenatal sensitization [57] or a protective role of maternal exposure during pregnancy [58].

De novo sensitization to food allergens through the airways has been described for some antigens, such as seeds and eggs, mainly as an occupational hazard resulting from release of particulates into the air during food processing [59]. Inhalation of lupine or sunflower seed flour and egg proteins by workers has been associated with sensitization and adverse reactions after consumption of foods containing these ingredients [6062]. Although the airway epithelium constitutes a barrier for the passage of inhaled allergens, environmental risk factors such as respiratory infections and cigarette smoke exposure, as well as genetic factors altering the epithelium, may contribute to the development of sensitization by inhalation [63].

\section{Skin Sensitization to Food Allergens}

There are several lines of evidence that support the hypothesis that early cutaneous exposure to food proteins through a disrupted skin barrier promotes allergic sensitization prior to the first ingestion of food, as opposed to the tolerogenic nature of oral exposure. This possibility led to the formulation of the dual exposure hypothesis, which suggests that exposure to food allergens through altered skin promotes sensitization, while early exposure to food allergens through the oral route promotes tolerance [64].

There is a strong association between atopic dermatitis (AD) and food sensitization [65]. Eczematous skin has been considered a major risk factor for development of food allergy [66,67], and children with AD environmentally exposed to peanut allergens show an increased risk of cutaneous sensitization to peanut $[68,69]$. In addition, impaired skin barrier function at birth has been described as predictive of food allergy at 2 years of age [70]. Moreover, mutations in Flg (encoding filaggrin) and SPINK5 (encoding serine peptidase inhibitor Kazal type 5), both of which are involved in the 
maintenance of skin barrier function, have been linked to development of food allergy [71-74]. Similar results have been found in mouse models [75]. Expression of homing markers on allergen-responsive $\mathrm{T}$ cells also supports the hypothesis that the initial priming of $\mathrm{T}$ cells is through the skin. $\mathrm{T}$ cells from peanut-allergic patients expressing cutaneous lymphocyte antigen (CLA), a skin-homing marker, showed an enhanced proliferative capacity to peanut compared with those that expressed $\alpha 4 \beta 7$ integrin, a gut- homing marker [76]. Similarly, peanut-specific T cells from peanut-allergic patients expressed the skin-homing marker CCR4, but low levels of $\beta 7$ [77].

Although topical exposure has been proposed as a main route of sensitization to food allergens, experimental models have demonstrated that skin exposure is not inherently sensitizing, as topical application of food allergens such as milk in the absence of external adjuvants leads to tolerance [78]. In addition to allergen exposure, epicutaneous sensitization to food allergens may require the effect of additional factors, including skin barrier damage [79] and presence of exogenous adjuvants such as toxins produced by microbes colonizing eczematous skin [22]. Some allergens, such as peanut, present intrinsic adjuvant activity and are able to activate DCs [80] and to sensitize epicutaneously without the use of external adjuvants $[22,81]$. Taken together, this evidence supports the hypothesis that, under conditions of skin barrier dysfunction or inflammation, sensitization to food allergens can be elicited through the skin.

In experimental models of skin sensitization, gastrointestinal symptoms are induced after oral challenge, demonstrating communication between skin and gut [46,82-84]. However, the exact mechanism by which this communication occurs has not been completely elucidated. Adjuvant activity in the skin induces the production of epithelial innate cytokines such as TSLP and IL-33, which promote $\mathrm{T}_{\mathrm{H}} 2$ responses. TSLP is upregulated in models that mimic atopic dermatitis, such as those that use tape stripping or the vitamin D analog MC903 [79,84]. In models of TSLP-mediated sensitization, basophils are essential for priming of $\mathrm{T}_{\mathrm{H}} 2$ responses and development of food allergy [83-86]. TSLP can act directly on basophils [87] or through a cascade initiated by DCs on the skin. DCs upregulate OX40L in response to TSLP and induce IL-3 expression by T cells, which recruits basophils to the lymph nodes [85]. The presence of basophils in the lymph nodes is essential for priming $\mathrm{CD}^{+} \mathrm{T}$ cells to express IL-4, suggesting that basophils could be an early source of IL-4. IL33 is also upregulated in tape stripping models of epicutaneous sensitization to food allergens [51]. Moreover, in a model of diarrhea induced by intradermal injection of TSLP and antigen, the IL-33 receptor ST2 was required for TSLP-driven gastrointestinal inflammation [88]. In this model, intradermal injection of IL-33 was sufficient to induce gastrointestinal symptoms in a TSLP-independent manner, suggesting that IL-33 could be acting downstream of TSLP.

In the absence of skin damage, TSLP is not upregulated, and IL-33 is central for the development of allergic sensitization to peanut [22]. IL-33 is produced by keratinocytes in response to topical peanut and polarizes skin DCs to drive $\mathrm{T}_{\mathrm{H}} 2$ responses. IL-33 is also implicated in skin sensitization using SEB as an adjuvant, although SEB induces a broader immunological response than peanut, with induction of both $\mathrm{T}_{\mathrm{H}} 2$ and Tfh cells in a mechanism dependent on IL-33 receptor (ST2), IL-1, and IL-6 [22].

Another epithelial cytokine, IL-25, has also been associated with induction of $\mathrm{T}_{\mathrm{H}} 2$ responses. Intestinal ILC2s respond to IL-25 stimulation by producing high levels of IL-5 and IL-13, which amplify $\mathrm{T}_{\mathrm{H}} 2$ responses [89]. IL-25 is required for the induction of gastrointestinal allergic responses during oral challenge as mice deficient in IL-25 were resistant to food allergy. However, the role of skin-derived IL-25 in the development of skin sensitization to food antigens needs to be elucidated.

Lipids carried by allergens can also act as immunomodulatory molecules to promote sensitization to allergens [90]. They can be presented by CD1 molecules expressed on the surface of antigen-presenting cells to iNKT cells acting as adjuvants for sensitization through the skin [91]. Nevertheless, the role of iNKT cells in skin sensitization to food allergens has not yet been determined. iNKT cells are at the interface between innate and adaptive immune responses and can contribute to allergic sensitization by producing $\mathrm{T}_{\mathrm{H}} 2$ cytokines. iNKT cells from cow's milk-allergic children produce higher levels of IL-4 and IL-13 than those from nonallergic children in response to stimulation with the lipids present in milk, thus suggesting their contribution to food allergy [92].

\section{Environmental Factors Affecting Food Allergy}

\section{Role of Microbiota and Diet}

Some studies have associated altered composition of gut microbiota with risk of developing food allergy $[93,94]$. In mouse models, food allergy has been associated with a microbiota signature that is different from that presented by mice that did not develop food allergy [95-97]. Furthermore, transplantation of microbiome from I14raF709 mice, which are prone to develop food allergy through the oral route, to germ-free mice transferred susceptibility to food allergy, thus highlighting the importance of microbiome composition in allergic sensitization to food [96]. Some bacterial strains, such as Clostridia, have been associated with protection from food allergy [97-99]. However, human studies investigating bacterial signatures associated with food allergy have yielded diverse results [100-102]. Thus, it is not clear yet which microbiota strains promote development of food allergy. Although most studies have focused on the contribution of gut microbiota, the skin is also colonized, and composition of skin microbiota may also play a role in regulating sensitization to food allergens.

The mechanisms by which microbiota can regulate tolerance or susceptibility to food allergens are diverse. One of the mechanisms that has been described is the regulation of intestinal barrier integrity. Clostridia-containing microbiota can enhance production of IL-22 by innate lymphoid cells and $\mathrm{CD}^{+} \mathrm{T}$ cells, resulting in reduced intestinal barrier permeability to peanut allergens [97]. In addition, colonization by Clostridia and Bacteroides promotes induction of $\operatorname{IgA}$, which can also reduce allergen transport throughout the epithelial barrier [97]. 
Several studies support the role of commensal microbiota in the regulation of tolerance to food allergens by Treg induction [103]. Germ-free and antibiotic-treated mice have shown a lack of Treg generation in the colonic lamina propria, which is restored following colonization [99,104106]. Clostridia species and other bacterial strains such as Bacteroides fragilis and Bifidobacterium species promote Treg expansion and enhance the regulatory tone of the host immune system [97-99, 107, 108]. The gut microbiota induces a subset of Tregs expressing ROR $\gamma \mathrm{t}^{+}$that suppress $\mathrm{T}_{\mathrm{H}} 2$ responses [109]. MyD88 signaling in Tregs is essential to be able to sense commensal microbiota and to induce mucosal tolerance [106]. Commensal-derived signals also regulate production of $\mathrm{IgE}$ antibodies. Germ-free mice and mice treated with antibiotics present increased basal levels of IgE. The presence of microbiota limits serum $\operatorname{IgE}$ and circulating basophils by a mechanism dependent on MyD88 expression by B cells [110].
Multiple studies support interaction between diet and commensal microbiota. Dietary habits induce changes in microbiome composition and bacteria-derived metabolites, regulating proinflammatory and tolerogenic responses to food proteins $[111,112]$. Carbohydrates that are indigestible for host enzymes, such as dietary fiber, can be fermented by the gut microbiota, which exerts a prebiotic effect that stimulates the growth of beneficial strains and inhibits colonization by pathogenic bacteria. Supplementation of maternal diet with galacto-oligosaccharides and inulin during pregnancy and breastfeeding has shown an indirect effect on offspring, giving rise to an increased proportion of Lactobacillus species and Clostridium leptum and decreased proportion of Clostridium coccoides and promoting immune tolerance to wheat gliadin in offspring [113]. In addition, bacterial metabolic products including short chain fatty acids (SCFAs) have been shown to directly regulate mucosal immune function and the intestinal

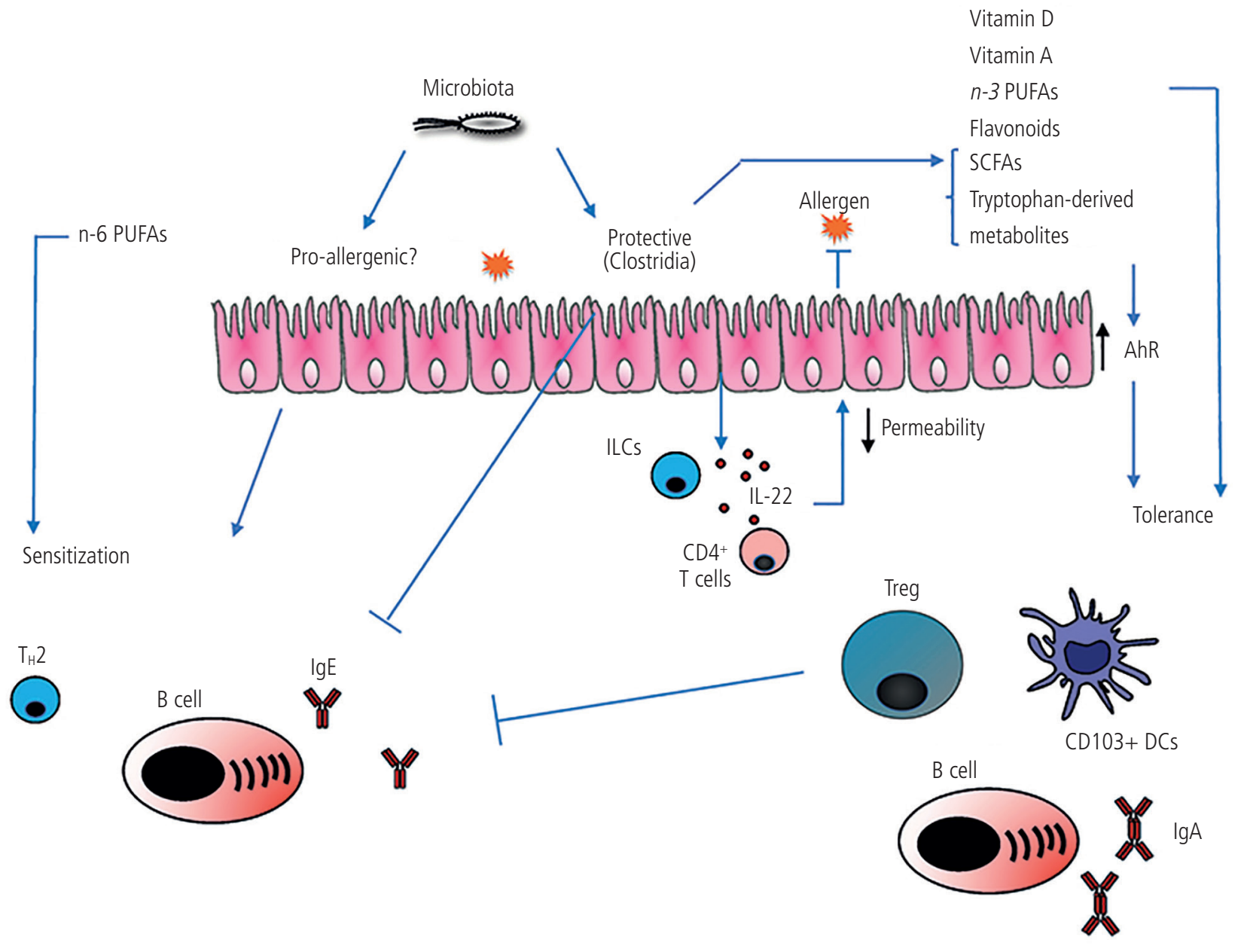

Figure 2. Role of microbiota and diet in the development of sensitization and tolerance to food antigens. Strains such as Clostridia have been associated with suppression of sensitization and induction of tolerance. They suppress IgE class-switching, promote Treg induction, and reduce intestinal barrier permeability through production of IL-22 by ILCS and CD4+ T cells. Colonization by microbiota can also promote induction of IgA, which can in turn contribute to reducing allergen transport throughout the epithelial barrier. Microbiota can also promote food allergy, suggesting that some strains can have a pro-allergenic role. Bacterial metabolic products such as SCFAs and dietary components such as vitamin D, vitamin A, flavonoids, and $n$-3 PUFAs promote tolerance to food allergens by enhancing the tolerogenic function of CD103+ DCs and Treg generation. Activation of aryl hydrocarbon receptor $(\mathrm{AhR})$ can be induced by tryptophan-derived metabolites generated by bacteria and has also been associated with suppression of allergic sensitization. By contrast, increased intake of n-6 PUFAs is related with promoting allergenic responses. AhR indicates aryl hydrocarbon receptor; DC, dendritic cell; PUFA indicates polyunsaturated fatty acid; SCFA, short-chain fatty acid. 
barrier [114]. Butyrate, a SCFA derived from bacterial metabolism of dietary fiber, has proven to have an important role in the promotion of functional Foxp3 ${ }^{+}$Tregs [115-117]. Dietary-derived bacterial SCFAs enhance the tolerogenic function of $\mathrm{CD}_{103^{+}} \mathrm{DCs}$ via metabolism of vitamin A and retinoic acid production, which is associated with Treg expansion and tolerance to food allergens [118]. Dietary intervention in infants showed that formula supplemented with Lactobacillus rhamnosus GG was able to expand butyrate-producing bacteria in the gut and alleviated the symptoms of cow's milk allergy [119].

Besides carbohydrates, degradation of dietary proteins by intestinal microbiota promotes generation of amino acidderived metabolites with immunomodulatory properties. Tryptophan-derived metabolites generated by bacteria can activate aryl hydrocarbon receptor (AhR) expressed by epithelial and immune cells [120,121]. Activation of AhR has been associated with suppression of allergic sensitization to egg and peanut allergens by generation of tolerogenic $\mathrm{CD} 103^{+}$ DCs and CD $25^{+} \mathrm{Foxp}^{+}$Treg cells $[122,123]$. In addition, most food allergens are partially resistant to host digestive enzymes, and intestinal microbiota may exert a direct effect on their allergenicity. In celiac disease, certain bacterial strains, such as Rothia species and Lactobacillus species, are able to degrade nondigested gluten peptides, thus reducing the immunogenicity of these compounds $[124,125]$. However, in the context of food allergies, microbial ability to modify food proteins needs to be further investigated.

\section{Other Dietary Factors}

Dietary factors can promote a tolerogenic gut environment through direct interaction with host immunity [105]. Low vitamin $\mathrm{D}$ levels in serum have been associated with increased risk of food allergy, while normal levels may confer protective effects [126-128]. Similarly, murine models have shown that vitamin D deficiency exacerbates allergic reactions mediated by increased levels of specific-IgE and reduced percentages of Foxp $3^{+}$Tregs, as well as an altered intestinal epithelial barrier $[129,130]$. Vitamin D can directly control IgE production by a mechanism dependent on B cell-derived IL10 , although the effect of vitamin $\mathrm{D}$ on other cell types is also implicated in the regulation of IgE levels [131]. Deficiency of dietary vitamin $\mathrm{A}$ has also been associated with breaking of oral tolerance through decreased expression of RALDH in CD103+ DCs [132]. In addition, intake of this vitamin is required for the efficient generation of ROR $\gamma \mathrm{t}+$ Treg cells in response to microbiota signals [109]. Intake of n-3 polyunsaturated fatty acids (PUFAs) has been found to reduce OVA-specific IgE and mast cell protease-1 (MCPT-1) levels and prevent sensitization to cow's milk $[133,134]$. In agreement with these results, administration of milk formula enriched in $n$-3 PUFAs showed a reduction of allergy incidence in early childhood [135]. By contrast, increased intake of vegetable oil rich in n-6 PUFAs has been described to promote allergenic response to whey proteins [136]. Other dietary components that have been associated with prevention of sensitization to food allergens include polyphenols, in particular flavonoids [137-139]. Thus, manipulation of dietary components may help to prevent development of food allergies. Figure 2 illustrates the role of microbiota and diet in sensitization and tolerance to food.

\section{Induction of Therapeutic Tolerance}

Allergen-specific immunotherapy is the most promising treatment currently under investigation for inducing tolerance to foods in allergic patients. Various routes of treatment are being investigated, including the oral, cutaneous, and sublingual routes, with oral immunotherapy (OIT) the most widely studied route. A subset of patients develop sustained unresponsiveness after cessation of therapy [140-145], with increased development of tolerance in young children. Biomarkers to predict effectiveness and durability of treatment have not yet been defined.

Figure 3 shows the different mechanisms proposed to mediate suppression of symptoms during allergen-specific immunotherapy to food. In general, allergen-specific immunotherapy has been associated with an early increase in allergen-specific IgE followed by a steady decrease, as well as increased allergen-specific IgG titers, in particular IgG4 [146-150]. As stated above, IgGs can block mast cell and basophil activation, leading to a reduction in $\mathrm{T}_{\mathrm{H}} 2$ responses and suppression of symptoms $[42,43,151]$. However, suppression of basophil responses during OIT is often transient, and levels of antigen-specific antibodies and basophil activation do not always correlate with development of long-lasting responses [143,152-154]. Increased polyclonal expansion and increased somatic mutation of IgG4 antibodies were found in patients receiving peanut OIT $[155,156]$. Furthermore, analysis of the BCR repertoire of Ara $\mathrm{h} 2$-specific memory $\mathrm{B}$ cells during peanut OIT revealed convergence in unrelated individuals [157], suggesting that development of a protective IgG4 repertoire able to inhibit IgE binding could be more associated with successful clinical outcome than antibody levels.

Results from human trials suggest that the mechanism mediating development of permanent tolerance after immunotherapy may not be the same as the one underlying primary oral tolerance to foods. In particular, there is some debate about the role of Tregs in the development of long-term protection. In some studies, oral immunotherapy has been associated with expansion of the Treg population [150]. Syed et al [154] found a correlation between induction of IL-10-expresing antigen-specific Tregs after peanut stimulation and development of sustained tolerance after OIT. By contrast, other studies found that OIT was associated with reduction of $\mathrm{T}_{\mathrm{H}} 2$ responses mediated by anergy, and there was no evidence of generation of antigen-specific Tregs in patients with sustained tolerance $[158,159]$.

Mouse studies support the hypothesis that induction of a functional Treg population may be required for the induction of long-term protection, as the lack of sustained tolerance observed after OIT has been associated with impaired generation of gastrointestinal Tregs $[29,35]$. In studies using IL4raF709 mice, Treg suppression during OIT was dependent on the presence of allergen-specific $\mathrm{IgE}$, and blockade of IgE signaling during OIT was effective in reestablishing induction of antigen-specific Tregs in allergic mice and desensitization to food allergens [35]. Blockade of IgE during OIT also promoted generation of functional Tregs in peanut-allergic patients, although the effect on sustained tolerance after cessation of therapy was not assessed 


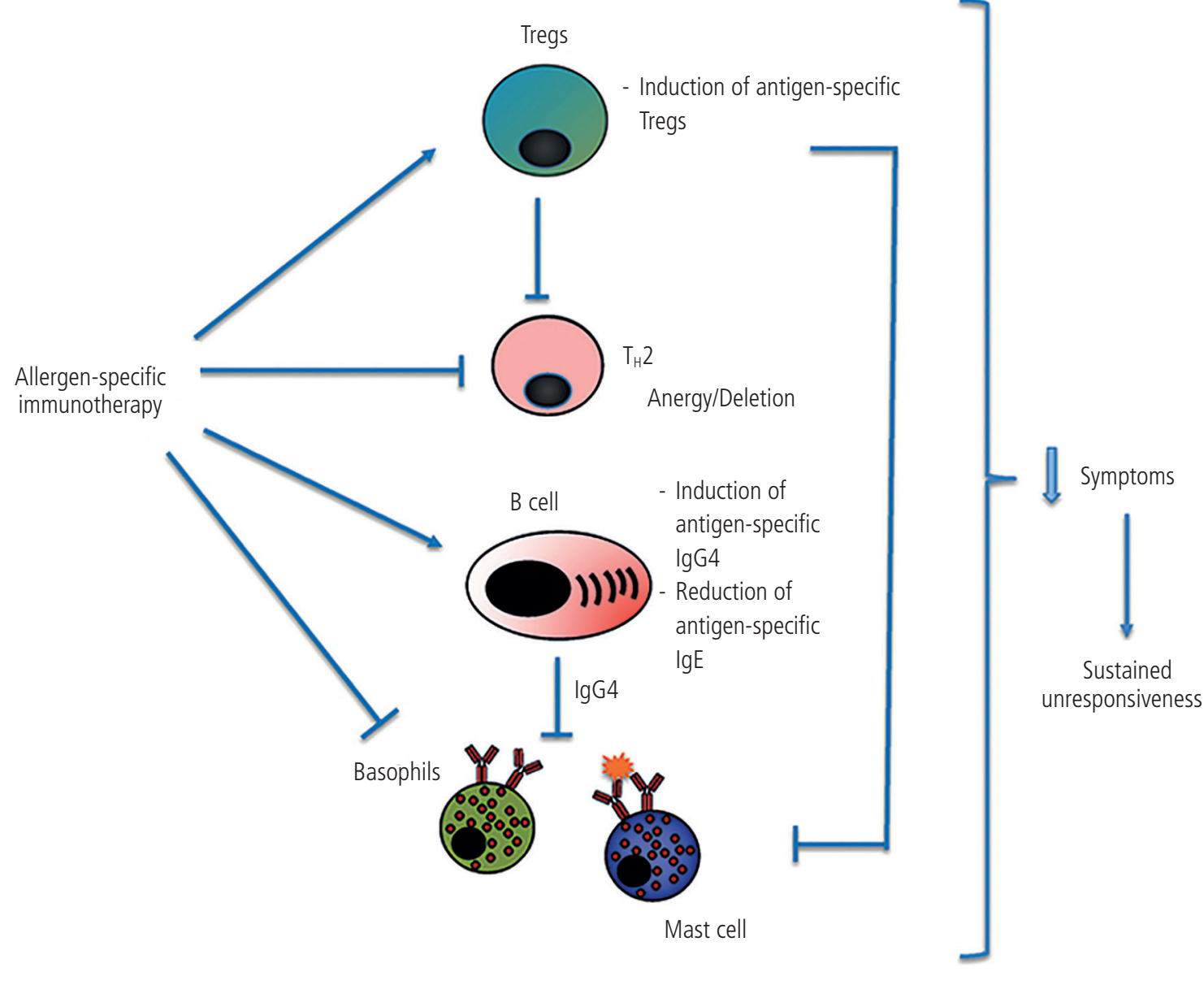

Figure 3. Impact of allergen-specific immunotherapy on the immune response to foods. Immunotherapy has been associated with induction of Tregs, which suppress $T_{H} 2$ responses and can also result in anergy or deletion of $T_{H} 2$ cells. B cells undergo somatic hypermutation, with induction of a diverse repertoire of antigen-specific lgG4 and reduced antigen-specific lgE. IgG4 antibodies can act as blocking antibodies. In addition, Tregs can directly block mast cell degranulation. These mechanisms contribute to suppression of symptoms during immunotherapy. The relationship between these mechanisms and clinical tolerance is still unknown.

[160]. Tregs were also shown to play a role in mediating protection during immunotherapy in a model of epicutaneous immunotherapy. This approach induced a population of LAP+ Tregs with gut homing properties able to suppress mast cell activation and food-induced anaphylaxis, even in the presence of high levels of antigen-specific IgE [29], suggesting that direct suppression of effector cells by Tregs is a mechanism involved in therapeutic tolerance.

\section{Conclusion}

There is growing evidence supporting the key role of nonoral routes, particularly the skin, in sensitization to food allergens. A key event during sensitization to food allergens is the production of epithelial cytokines, such as TSLP, IL-33, and IL-25, as well as IL-9, which is essential for amplification of allergic responses. Early introduction of foods aims to decrease the prevalence of food allergy in children through the process of oral tolerance. Whether permanent tolerance to food allergens can be induced in food-allergic patients in response to immunotherapy remains to be elucidated, although longterm follow up indicates that there is sustained benefit [142]. Studies with larger cohorts and longer follow-up of patients are necessary to correlate immune modifications with clinical outcome.

The use of combined therapies such as OIT in the presence of antibodies blocking IgE signaling and/or IL-9 may be an effective strategy for the successful induction of Tregs in the gut of food-allergic patients and potentially increase the proportion of patients reaching sustained unresponsiveness after immunotherapy. In addition, manipulation of environmental factors such as microbiota and diet to promote tolerance to foods may lead to more effective immunotherapy options and prevention strategies.

\section{Acknowledgments}

DL-O is the recipient of a postdoctoral fellowship funded by the Spanish Fundación Alfonso Martín Escudero. 


\section{Funding}

The authors declare that no funding was received for the present manuscript.

\section{Conflicts of Interest}

The authors declare that they have no conflicts of interest.

\section{References}

1. Coombes JL, Siddiqui KR, Arancibia-Carcamo CV, Hall J, Sun CM, Belkaid Y, et al. A functionally specialized population of mucosal CD103+ DCs induces Foxp3+ regulatory T cells via a TGF-beta and retinoic acid-dependent mechanism. J Exp Med. 2007;204(8):1757-64.

2. Esterhazy D, Loschko J, London M, Jove V, Oliveira TY, Mucida D. Classical dendritic cells are required for dietary antigenmediated induction of peripheral T(reg) cells and tolerance. Nat Immunol. 2016;17(5):545-55.

3. Sun CM, Hall JA, Blank RB, Bouladoux N, Oukka M, Mora JR, et al. Small intestine lamina propria dendritic cells promote de novo generation of Foxp3 T reg cells via retinoic acid. J Exp Med. 2007;204(8):1775-85.

4. Iwata M, Hirakiyama A, Eshima Y, Kagechika H, Kato C, Song SY. Retinoic acid imprints gut-homing specificity on $\mathrm{T}$ cells. Immunity. 2004;21(4):527-38.

5. Hadis U, Wahl B, Schulz O, Hardtke-Wolenski M, Schippers A, Wagner $\mathrm{N}$, et al. Intestinal tolerance requires gut homing and expansion of FoxP3+ regulatory $T$ cells in the lamina propria. Immunity. 2011;34(2):237-46.

6. Torgerson TR, Linane A, Moes N, Anover S, Mateo V, RieuxLaucat $F$, et al. Severe food allergy as a variant of IPEX syndrome caused by a deletion in a noncoding region of the FOXP3 gene. Gastroenterology. 2007;132(5):1705-17.

7. McDole JR, Wheeler LW, McDonald KG, Wang B, Konjufca $V$, Knoop $K A$, et al. Goblet cells deliver luminal antigen to CD103+ dendritic cells in the small intestine. Nature. 2012;483(7389):345-9.

8. Shan M, Gentile M, Yeiser JR, Walland AC, Bornstein VU, Chen $\mathrm{K}$, et al. Mucus enhances gut homeostasis and oral tolerance by delivering immunoregulatory signals. Science. 2013;342(6157):447-53.

9. Mortha A, Chudnovskiy A, Hashimoto D, Bogunovic M, Spencer SP, Belkaid Y, et al. Microbiota-dependent crosstalk between macrophages and ILC3 promotes intestinal homeostasis. Science. 2014;343(6178):1249288.

10. Du Toit G, Katz Y, Sasieni P, Mesher D, Maleki SJ, Fisher HR, et al. Early consumption of peanuts in infancy is associated with a low prevalence of peanut allergy. J Allergy Clin Immunol. 2008;122(5):984-91.

11. Kull I, Bergstrom A, Lilja G, Pershagen G, Wickman M. Fish consumption during the first year of life and development of allergic diseases during childhood. Allergy. 2006;61(8):1009-15.

12. Poole JA, Barriga K, Leung DY, Hoffman M, Eisenbarth GS, Rewers $\mathrm{M}$, et al. Timing of initial exposure to cereal grains and the risk of wheat allergy. Pediatrics. 2006;117(6):2175-82.

13. Du Toit G, Sayre PH, Roberts G, Sever ML, Lawson K, Bahnson HT, et al. Effect of Avoidance on Peanut Allergy after Early Peanut Consumption. N Engl J Med. 2016;374(15):1435-43.
14. Perkin MR, Logan K, Tseng A, Raji B, Ayis S, Peacock J, et al. Randomized Trial of Introduction of Allergenic Foods in BreastFed Infants. N Engl J Med. 2016;374(18):1733-43.

15. Bellach J, Schwarz V, Ahrens B, Trendelenburg V, Aksunger $O$ Kalb B, et al. Randomized placebo-controlled trial of hen's egg consumption for primary prevention in infants. J Allergy Clin Immunol. 2017;139(5):1591-9 e2.

16. Natsume O, Kabashima S, Nakazato J, Yamamoto-Hanada $\mathrm{K}$, Narita $\mathrm{M}$, Kondo $\mathrm{M}$, et al. Two-step egg introduction for prevention of egg allergy in high-risk infants with eczema (PETIT): a randomised, double-blind, placebo-controlled trial. Lancet. 2017:389(10066):276-86.

17. Palmer DJ, Sullivan TR, Gold MS, Prescott SL, Makrides M. Randomized controlled trial of early regular egg intake to prevent egg allergy. JAllergy Clin Immunol. 2017;139(5):16007 e2.

18. Wei-Liang Tan J, Valerio C, Barnes EH, Turner PJ, Van Asperen PA, Kakakios AM, et al. A randomized trial of egg introduction from 4 months of age in infants at risk for egg allergy. J Allergy Clin Immunol. 2017;139(5):1621-8 e8.

19. Ierodiakonou D, Garcia-Larsen V, Logan A, Groome A, Cunha $S$, Chivinge $J$, et al. Timing of Allergenic Food Introduction to the Infant Diet and Risk of Allergic or Autoimmune Disease: A Systematic Review and Meta-analysis. JAMA. 2016:316(11):1181-92.

20. Crotty S. Follicular helper CD4T cells (TFH). Annu Rev Immunol. 2011;29:621-63.

21. Dolence JJ, Kobayashi T, lijima K, Krempski J, Drake LY, Dent AL, et al. Airway exposure initiates peanut allergy by involving the IL-1 pathway and T follicular helper cells in mice. J Allergy Clin Immunol. 2018:142(4):1144-58 e8.

22. Tordesillas L, Goswami R, Benede S, Grishina G, Dunkin $D$, Jarvinen $K M$, et al. Skin exposure promotes a Th2dependent sensitization to peanut allergens. J Clin Invest. 2014;124(11):4965-75

23. Bailon E, Cueto-Sola M, Utrilla P, Rodriguez-Ruiz J, GarridoMesa N, Zarzuelo A, et al. A shorter and more specific oral sensitization-based experimental model of food allergy in mice. J Immunol Methods. 2012;381(1-2):41-9.

24. Li XM, Schofield BH, Huang CK, Kleiner GI, Sampson HA. A murine model of IgE-mediated cow's milk hypersensitivity. J Allergy Clin Immunol. 1999;103(2 Pt 1):206-14.

25. Blazquez $A B$, Berin MC. Gastrointestinal dendritic cells promote Th2 skewing via OX40L. J Immunol. 2008;180(7):4441-50.

26. Chu DK, Llop-Guevara A, Walker TD, Flader K, Goncharova S, Boudreau JE, et al. IL-33, but not thymic stromal lymphopoietin or IL-25, is central to mite and peanut allergic sensitization. J Allergy Clin Immunol. 2013:131(1):187-200 e1-8.

27. Chu DK, Jimenez-Saiz R, Verschoor CP, Walker TD, Goncharova S, Llop-Guevara A, et al. Indigenous enteric eosinophils control DCs to initiate a primary Th2 immune response in vivo. J Exp Med. 2014:211(8):1657-72.

28. Kong J, Chalcraft K, Mandur TS, Jimenez-Saiz R, Walker TD, Goncharova S, et al. Comprehensive metabolomics identifies the alarmin uric acid as a critical signal for the induction of peanut allergy. Allergy. 2015;70(5):495-505.

29. Tordesillas L, Mondoulet $L$, Blazquez $A B$, Benhamou $P H$ Sampson HA, Berin MC. Epicutaneous immunotherapy induces gastrointestinal $\mathrm{LAP}+$ regulatory $\mathrm{T}$ cells and 
prevents food-induced anaphylaxis. J Allergy Clin Immunol. 2017;139(1):189-201 e4.

30. Cho SH, Strickland I, Boguniewicz M, Leung DY. Fibronectin and fibrinogen contribute to the enhanced binding of Staphylococcus aureus to atopic skin. J Allergy Clin Immunol. 2001;108(2):269-74.

31. Yang PC, Xing Z, Berin CM, Soderholm JD, Feng BS, Wu L, et al. TIM-4 expressed by mucosal dendritic cells plays a critical role in food antigen-specific Th2 differentiation and intestinal allergy. Gastroenterology. 2007;133(5):1522-33.

32. Ganeshan K, Neilsen CV, Hadsaitong A, Schleimer RP, Luo $X$, Bryce PJ. Impairing oral tolerance promotes allergy and anaphylaxis: a new murine food allergy model. J Allergy Clin Immunol. 2009;123(1):231-8 e4.

33. Mathias CB, Hobson SA, Garcia-Lloret M, Lawson G, Poddighe D, Freyschmidt EJ, et al. IgE-mediated systemic anaphylaxis and impaired tolerance to food antigens in mice with enhanced IL-4 receptor signaling. J Allergy Clin Immunol. 2011;127(3):795-805 e1-6.

34. Hershey GK, Friedrich MF, Esswein LA, Thomas ML, Chatila TA. The association of atopy with a gain-of-function mutation in the alpha subunit of the interleukin-4 receptor. N Engl J Med. 1997;337(24):1720-5.

35. Burton OT, Noval Rivas M, Zhou JS, Logsdon SL, Darling AR, Koleoglou KJ, et al. Immunoglobulin E signal inhibition during allergen ingestion leads to reversal of established food allergy and induction of regulatory T cells. Immunity. 2014;41(1):141-51.

36. Noval Rivas M, Burton OT, Wise P, Charbonnier LM, Georgiev $\mathrm{P}$, Oettgen $\mathrm{HC}$, et al. Regulatory T Cell Reprogramming toward a Th2-Cell-like Lineage Impairs Oral Tolerance and Promotes Food Allergy. Immunity. 2015;42(3):512-23.

37. Noval Rivas M, Burton OT, Oettgen HC, Chatila T. IL-4 production by group 2 innate lymphoid cells promotes food allergy by blocking regulatory T-cell function. J Allergy Clin Immunol. 2016;138(3):801-11 e9.

38. Karlsson MR, Rugtveit J, Brandtzaeg P. Allergen-responsive CD4+CD25+ regulatory $T$ cells in children who have outgrown cow's milk allergy. J Exp Med. 2004;199(12):1679-88.

39. Qamar N, Fishbein AB, Erickson KA, Cai M, Szychlinski C, Bryce PJ, et al. Naturally occurring tolerance acquisition to foods in previously allergic children is characterized by antigen specificity and associated with increased subsets of regulatory T cells. Clin Exp Allergy. 2015;45(11):1663-72.

40. Chiang D, Chen X, Jones SM, Wood RA, Sicherer SH, Burks AW, et al. Single-cell profiling of peanut-responsive T cells in patients with peanut allergy reveals heterogeneous effector TH2 subsets. J Allergy Clin Immunol. 2018;141(6):2107-20.

41. Du Toit G, Roberts G, Sayre PH, Bahnson HT, Radulovic S, Santos $A F$, et al. Randomized trial of peanut consumption in infants at risk for peanut allergy. N Engl J Med. 2015;372(9):803-13.

42. Santos AF, James LK, Bahnson HT, Shamji MH, CoutoFrancisco NC, Islam $S$, et al. IgG inhibits peanut-induced basophil and mast cell activation in peanut-tolerant children sensitized to peanut major allergens. J Allergy Clin Immunol. 2015;133(5):1249-56.

43. Burton OT, Tamayo JM, Stranks AJ, Koleoglou KJ, Oettgen HC. Allergen-specific IgG antibody signaling through FcgammaRIllb promotes food tolerance. J Allergy Clin Immunol. 2018;141(1):189-201 e3.
44. Ohsaki A, Venturelli N, Buccigrosso TM, Osganian SK, Lee J, Blumberg RS, et al. Maternal IgG immune complexes induce food allergen-specific tolerance in offspring. J Exp Med. 2018;215(1):91-113.

45. Benede S, Berin MC. Mast cell heterogeneity underlies different manifestations of food allergy in mice. PLoS One. 2018;13(1):e0190453.

46. Chen CY, Lee JB, Liu B, Ohta S, Wang PY, Kartashov AV, et al. Induction of Interleukin-9-Producing Mucosal Mast Cells Promotes Susceptibility to IgE-Mediated Experimental Food Allergy. Immunity. 2015;43(4):788-802.

47. Forbes EE, Groschwitz K, Abonia JP, Brandt EB, Cohen E, Blanchard C, et al. IL-9- and mast cell-mediated intestinal permeability predisposes to oral antigen hypersensitivity. J Exp Med. 2008;205(4):897-913.

48. Osterfeld $H$, Ahrens R, Strait R, Finkelman FD, Renauld $J C$, Hogan SP. Differential roles for the IL-9/IL-9 receptor alpha-chain pathway in systemic and oral antigen-induced anaphylaxis. J Allergy Clin Immunol. 2010;125(2):469-76 e2.

49. Brough HA, Cousins DJ, Munteanu A, Wong YF, Sudra A, Makinson K, et al. IL-9 is a key component of memory TH cell peanut-specific responses from children with peanut allergy. J Allergy Clin Immunol. 2014;134(6):1329-38 e10.

50. Kosoy R, Agashe C, Grishin A, Leung DY, Wood RA, Sicherer SH, et al. Transcriptional Profiling of Egg Allergy and Relationship to Disease Phenotype. PLoS One. 2016;11(10):e0163831.

51. Galand C, Leyva-Castillo JM, Yoon J, Han A, Lee MS, McKenzie AN, et al. IL-33 promotes food anaphylaxis in epicutaneously sensitized mice by targeting mast cells. J Allergy Clin Immunol. 2016;138(5):1356-66.

52. Burton OT, Medina Tamayo J, Stranks AJ, Miller S, Koleoglou KJ, Weinberg EO, et al. IgE promotes type 2 innate lymphoid cells in murine food allergy. Clin Exp Allergy. 2018;48(3):288-96.

53. Lefrancais E, Duval A, Mirey E, Roga S, Espinosa E, Cayrol C, et al. Central domain of IL-33 is cleaved by mast cell proteases for potent activation of group-2 innate lymphoid cells. Proc Natl Acad Sci U S A. 2014;111(43):15502-7.

54. Sicherer SH, Burks AW, Sampson HA. Clinical features of acute allergic reactions to peanut and tree nuts in children. Pediatrics. 1998;102(1):e6.

55. Kamemura N, Tada H, Shimojo N, Morita Y, Kohno Y, Ichioka $T$, et al. Intrauterine sensitization of allergen-specific IgE analyzed by a highly sensitive new allergen microarray. J Allergy Clin Immunol. 2012;130(1):113-21 e2.

56. Sicherer SH, Wood RA, Stablein D, Lindblad R, Burks AW, Liu $\mathrm{AH}$, et al. Maternal consumption of peanut during pregnancy is associated with peanut sensitization in atopic infants. J Allergy Clin Immunol. 2010;126(6):1191-7.

57. Lack G, Fox D, Northstone K, Golding J; Avon Longitudinal Study of Parents and Children Study Team. Factors associated with the development of peanut allergy in childhood. N Engl J Med. 2003;348(11):977-85.

58. Bunyavanich S, Rifas-Shiman SL, Platts-Mills TA, Workman L, Sordillo JE, Camargo CA, Jr., et al. Peanut, milk, and wheat intake during pregnancy is associated with reduced allergy and asthma in children. J Allergy Clin Immunol. 2014;133(5):137382.

59. Ramirez DA, Jr. and Bahna SL. Food hypersensitivity by inhalation. Clin Mol Allergy. 2009;7:4. 
60. Crespo JF, Rodriguez J, Vives R, James JM, Reano M, Daroca $P$, et al. Occupational lgE-mediated allergy after exposure to lupine seed flour. J Allergy Clin Immunol. 2001;108(2):295-7.

61. Leser C, Hartmann AL, Praml G, Wuthrich B. The "egg-egg" syndrome: occupational respiratory allergy to airborne egg proteins with consecutive ingestive egg allergy in the bakery and confectionery industry. J Investig Allergol Clin Immunol. 2001;11(2):89-93.

62. Palma-Carlos $A G$, Palma-Carlos $M L$, and Tengarrinha $F$. Allergy to sunflower seeds. Eur Ann Allergy Clin Immunol. 2005;37(5):183-6.

63. Lambrecht BN, Hammad $H$. Allergens and the airway epithelium response: gateway to allergic sensitization. J Allergy Clin Immunol. 2014;134(3):499-507.

64. Lack G. Update on risk factors for food allergy. J Allergy Clin Immunol. 2012;129(5):1187-97.

65. Tsakok T, Marrs T, Mohsin M, Baron S, du Toit G, Till S, et al. Does atopic dermatitis cause food allergy? A systematic review. J Allergy Clin Immunol. 2016;137(4):1071-8.

66. Loo EX, Sim JZ, Goh A, Teoh OH, Chan YH, Saw SM, et al. Predictors of allergen sensitization in Singapore children from birth to 3 years. Allergy Asthma Clin Immunol. 2016;12:56.

67. Martin PE, Eckert JK, Koplin JJ, Lowe AJ, Gurrin LC, Dharmage SC, et al. Which infants with eczema are at risk of food allergy? Results from a population-based cohort. Clin Exp Allergy. 2015;45(1):255-64.

68. Brough HA, Liu AH, Sicherer S, Makinson K, Douiri A, Brown $S J$, et al. Atopic dermatitis increases the effect of exposure to peanut antigen in dust on peanut sensitization and likely peanut allergy. J Allergy Clin Immunol. 2015;135(1):164-70.

69. Brough HA, Santos AF, Makinson K, Penagos M, Stephens AC, Douiri $A$, et al. Peanut protein in household dust is related to household peanut consumption and is biologically active. J Allergy Clin Immunol. 2013;132(3):630-8.

70. Kelleher MM, Dunn-Galvin A, Gray C, Murray DM, Kiely $M$, Kenny $L$, et al. Skin barrier impairment at birth predicts food allergy at 2 years of age. J Allergy Clin Immunol. 2016;137(4):1111-6 e8.

71. Ashley SE, Tan HT, Vuillermin P, Dharmage SC, Tang MLK, Koplin $J$, et al. The skin barrier function gene SPINK5 is associated with challenge-proven IgE-mediated food allergy in infants. Allergy. 2017;72(9):1356-64.

72. Brough HA, Simpson A, Makinson K, Hankinson J, Brown S, Douiri $A$, et al. Peanut allergy: effect of environmental peanut exposure in children with filaggrin loss-of-function mutations. J Allergy Clin Immunol. 2014;134(4):867-75 e1.

73. Marenholz I, Grosche S, Kalb B, Ruschendorf F, Blumchen K, Schlags $R$, et al. Genome-wide association study identifies the SERPINB gene cluster as a susceptibility locus for food allergy. Nat Commun. 2017;8(1):1056.

74. Venkataraman D, Soto-Ramirez N, Kurukulaaratchy RJ, Holloway JW, Karmaus W, Ewart SL, et al. Filaggrin lossof-function mutations are associated with food allergy in childhood and adolescence. J Allergy Clin Immunol. 2014;134(4):876-82 e4.

75. Walker MT, Green JE, Ferrie RP, Queener AM, Kaplan MH, CookMills JM. Mechanism for initiation of food allergy: Dependence on skin barrier mutations and environmental allergen costimulation. J Allergy Clin Immunol. 2018;141(5):1711-25 e9.
76. Chan SM, Turcanu V, Stephens AC, Fox AT, Grieve AP, Lack G. Cutaneous lymphocyte antigen and alpha4beta7 T-lymphocyte responses are associated with peanut allergy and tolerance in children. Allergy. 2012;67(3):336-42.

77. DeLong JH, Simpson KH, Wambre E, James EA, Robinson D, Kwok WW. Ara h 1-reactive T cells in individuals with peanut allergy. J Allergy Clin Immunol. 2011;127(5):1211-8 e3.

78. Dunkin D, Berin MC, Mayer L. Allergic sensitization can be induced via multiple physiologic routes in an adjuvant-dependent manner. J Allergy Clin Immunol. 2011;128(6):1251-8 e2.

79. Oyoshi MK, Larson RP, Ziegler SF, Geha RS. Mechanical injury polarizes skin dendritic cells to elicit a $\mathrm{T}(\mathrm{H}) 2$ response by inducing cutaneous thymic stromal lymphopoietin expression. J Allergy Clin Immunol. 2010;126(5):976-84, 84 e1-5.

80. Shreffler WG, Castro RR, Kucuk ZY, Charlop-Powers Z, Grishina G, Yoo S, et al. The major glycoprotein allergen from Arachis hypogaea, Ara $\mathrm{h} 1$, is a ligand of dendritic cell-specific ICAMgrabbing nonintegrin and acts as a Th2 adjuvant in vitro. J Immunol. 2006;177(6):3677-85.

81. Shimura S, Takai T, lida H, Maruyama N, Ochi H, Kamijo S, et al. Epicutaneous Allergic Sensitization by Cooperation between Allergen Protease Activity and Mechanical Skin Barrier Damage in Mice. J Invest Dermatol. 2016;136(7):1408-17.

82. Bartnikas LM, Gurish MF, Burton OT, Leisten $S$, Janssen $E$, Oettgen $\mathrm{HC}$, et al. Epicutaneous sensitization results in lgEdependent intestinal mast cell expansion and food-induced anaphylaxis. J Allergy Clin Immunol. 2013;131(2):451-60 e1-6.

83. Han H, Thelen TD, Comeau MR, Ziegler SF. Thymic stromal lymphopoietin-mediated epicutaneous inflammation promotes acute diarrhea and anaphylaxis. J Clin Invest. 2014;124(12): 5442-52.

84. Noti M, Kim BS, Siracusa MC, Rak GD, Kubo M, Moghaddam $A E$, et al. Exposure to food allergens through inflamed skin promotes intestinal food allergy through the thymic stromal lymphopoietin-basophil axis. J Allergy Clin Immunol. 2014;133(5):1390-9, 9 e 1-6.

85. Leyva-Castillo JM, Hener P, Michea P, Karasuyama H, Chan S, Soumelis $V$, et al. Skin thymic stromal lymphopoietin initiates Th2 responses through an orchestrated immune cascade. Nat Commun. 2013;4:2847

86. Muto T, Fukuoka A, Kabashima K, Ziegler SF, Nakanishi K, Matsushita $K$, et al. The role of basophils and proallergic cytokines, TSLP and IL-33, in cutaneously sensitized food allergy. Int Immunol. 2014;26(10):539-49.

87. Siracusa MC, Saenz SA, Hill DA, Kim BS, Headley MB, Doering TA, et al. TSLP promotes interleukin-3-independent basophil haematopoiesis and type 2 inflammation. Nature. 2011;477(7363):229-33.

88. Han H, Roan F, Johnston LK, Smith DE, Bryce PJ, Ziegler SF. IL-33 promotes gastrointestinal allergy in a TSLP-independent manner. Mucosal Immunol. 2018;11(2):394-403.

89. Lee JB, Chen CY, Liu B, Mugge L, Angkasekwinai P, Facchinetti $V$, et al. IL-25 and CD4(+) TH2 cells enhance type 2 innate lymphoid cell-derived IL-13 production, which promotes IgEmediated experimental food allergy. J Allergy Clin Immunol. 2016;137(4):1216-25 e1-5.

90. Bublin M, Eiwegger T, Breiteneder H. Do lipids influence the allergic sensitization process? J Allergy Clin Immunol. 2014;134(3):521-9. 
91. Tordesillas L, Cubells-Baeza N, Gomez-Casado C, Berin C, Esteban V, Barcik W, et al. Mechanisms underlying induction of allergic sensitization by Pru p 3. Clin Exp Allergy. 2017;47(11):1398-408.

92. Jyonouchi S, Abraham V, Orange JS, Spergel JM, Gober L,

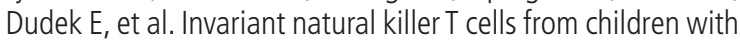
versus without food allergy exhibit differential responsiveness to milk-derived sphingomyelin. J Allergy Clin Immunol. 2011;128(1):102-9 e13.

93. Gensollen T, Blumberg RS. Correlation between early-life regulation of the immune system by microbiota and allergy development. J Allergy Clin Immunol. 2017;139(4):1084-91.

94. Huang YJ, Marsland BJ, Bunyavanich S, O'Mahony L, Leung DY, Muraro A, et al. The microbiome in allergic disease: Current understanding and future opportunities-2017 PRACTALL document of the American Academy of Allergy, Asthma \& Immunology and the European Academy of Allergy and Clinical Immunology. J Allergy Clin Immunol. 2017;139(4):1099-110.

95. Diesner SC, Bergmayr C, Pfitzner B, Assmann V, Krishnamurthy $D$, Starkl $P$, et al. A distinct microbiota composition is associated with protection from food allergy in an oral mouse immunization model. Clin Immunol. 2016;173:10-8.

96. Noval Rivas M, Burton OT, Wise P, Zhang YQ, Hobson SA, Garcia Lloret $M$, et al. A microbiota signature associated with experimental food allergy promotes allergic sensitization and anaphylaxis. J Allergy Clin Immunol. 2013;131(1):201-12.

97. Stefka AT, Feehley T, Tripathi P, Qiu J, McCoy K, Mazmanian SK, et al. Commensal bacteria protect against food allergen sensitization. Proc Natl Acad Sci U S A. 2014;111(36):1314550.

98. Atarashi K, Tanoue T, Oshima K, Suda W, Nagano Y, Nishikawa $\mathrm{H}$, et al. Treg induction by a rationally selected mixture of Clostridia strains from the human microbiota. Nature. 2013;500(7461):232-6.

99. Atarashi K, Tanoue T, Shima T, Imaoka A, Kuwahara T, Momose $Y$, et al. Induction of colonic regulatory $T$ cells by indigenous Clostridium species. Science. 2011;331(6015):337-41.

100. Hua X, Goedert JJ, Pu A, Yu G, Shi J. Allergy associations with the adult fecal microbiota: Analysis of the American Gut Project. EBioMedicine. 2016;3:172-9.

101. Ling Z, Li Z, Liu X, Cheng Y, Luo Y, Tong X, et al. Altered fecal microbiota composition associated with food allergy in infants. Appl Environ Microbiol. 2014;80(8):2546-54.

102. Fazlollahi M, Chun Y, Grishin A, Wood RA, Burks AW, Dawson $P$, et al. Early-life gut microbiome and egg allergy. Allergy. 2018;73(7):1515-24.

103. Plunkett $\mathrm{CH}$ and Nagler CR. The Influence of the Microbiome on Allergic Sensitization to Food. J Immunol. 2017;198(2):581-9.

104. Geuking MB, Cahenzli J, Lawson MA, Ng DC, Slack E, Hapfelmeier $S$, et al. Intestinal bacterial colonization induces mutualistic regulatory $\mathrm{T}$ cell responses. Immunity. 2011;34(5):794-806.

105. Kim KS, Hong SW, Han D, Yi J, Jung J, Yang BG, et al. Dietary antigens limit mucosal immunity by inducing regulatory $T$ cells in the small intestine. Science. 2016;351(6275):858-63.

106. Wang S, Charbonnier LM, Noval Rivas M, Georgiev P, Li N, Gerber G, et al. MyD88 Adaptor-Dependent Microbial Sensing by Regulatory $\mathrm{T}$ Cells Promotes Mucosal Tolerance and Enforces Commensalism. Immunity. 2015;43(2):289-303.
107. Faith JJ, Ahern PP, Ridaura VK, Cheng J, Gordon JI. Identifying gut microbe-host phenotype relationships using combinatorial communities in gnotobiotic mice. Sci Transl Med. 2014;6(220):220ra11.

108. Lyons A, O'Mahony D, O'Brien F, MacSharry J, Sheil B, Ceddia $M$, et al. Bacterial strain-specific induction of Foxp3+ T regulatory cells is protective in murine allergy models. Clin Exp Allergy. 2010;40(5):811-9.

109. Ohnmacht C, Park JH, Cording S, Wing JB, Atarashi K, Obata $Y$, et al. MUCOSAL IMMUNOLOGY. The microbiota regulates type 2 immunity through RORgammat(+) T cells. Science. 2015;349(6251):989-93.

110. Hill DA, Siracusa MC, Abt MC, Kim BS, Kobuley D, Kubo $M$, et al. Commensal bacteria-derived signals regulate basophil hematopoiesis and allergic inflammation. Nat Med. 2012;18(4):538-46.

111. Shibata N, Kunisawa J, Kiyono H. Dietary and Microbial Metabolites in the Regulation of Host Immunity. Front Microbiol. 2017;8:2171.

112. Zhou X, Du L, Shi R, Chen Z, Zhou Y, Li Z. Early-life food nutrition, microbiota maturation and immune development shape life-long health. Crit Rev Food Sci Nutr. 2018:1-9.

113. Bouchaud G, Castan L, Chesne J, Braza F, Aubert P, Neunlist M, et al. Maternal exposure to GOS/inulin mixture prevents food allergies and promotes tolerance in offspring in mice. Allergy. 2016;71(1):68-76.

114. Morrison DJ, Preston T. Formation of short chain fatty acids by the gut microbiota and their impact on human metabolism. Gut Microbes. 2016;7(3):189-200.

115. Arpaia N, Campbell C, Fan X, Dikiy S, van der Veeken J, deRoos $\mathrm{P}$, et al. Metabolites produced by commensal bacteria promote peripheral regulatory T-cell generation. Nature. 2013;504(7480):451-5.

116. Furusawa Y, Obata Y, Fukuda S, Endo TA, Nakato G, Takahashi $D$, et al. Commensal microbe-derived butyrate induces the differentiation of colonic regulatory $T$ cells. Nature. 2013;504(7480):446-50.

117. Smith PM, Howitt MR, Panikov N, Michaud M, Gallini CA, Bohlooly YM, et al. The microbial metabolites, short-chain fatty acids, regulate colonic Treg cell homeostasis. Science. 2013;341(6145):569-73.

118. Tan J, McKenzie C, Vuillermin PJ, Goverse G, Vinuesa CG, Mebius RE, et al. Dietary Fiber and Bacterial SCFA Enhance Oral Tolerance and Protect against Food Allergy through Diverse Cellular Pathways. Cell Rep. 2016;15(12):280924.

119. Berni Canani R, Sangwan N, Stefka AT, Nocerino R, Paparo L, Aitoro R, et al. Lactobacillus rhamnosus GG-supplemented formula expands butyrate-producing bacterial strains in food allergic infants. ISME J. 2016;10(3):742-50.

120. Lamas B, Richard ML, Leducq V, Pham HP, Michel ML, Da Costa $\mathrm{G}$, et al. CARD9 impacts colitis by altering gut microbiota metabolism of tryptophan into aryl hydrocarbon receptor ligands. Nat Med. 2016;22(6):598-605.

121. Schulz VJ, Smit JJ, Pieters RH. The aryl hydrocarbon receptor and food allergy. Vet Q. 2013;33(2):94-107.

122. Hammerschmidt-Kamper C, Biljes D, Merches K, Steiner I, Daldrup $T$, Bol-Schoenmakers $M$, et al. Indole-3-carbinol, a plant nutrient and AhR-Ligand precursor, supports oral 
tolerance against OVA and improves peanut allergy symptoms in mice. PLoS One. 2017;12(6):e0180321.

123. Schulz VJ, van Roest M, Bol-Schoenmakers $M$, van Duursen $M B$, van den Berg $M$, Pieters $\mathrm{RH}$, et al. Aryl hydrocarbon receptor activation affects the dendritic cell phenotype and function during allergic sensitization. Immunobiology. 2013;218(8):1055-62.

124. Caminero A, Galipeau HJ, McCarville JL, Johnston CW, Bernier SP, Russell AK, et al. Duodenal Bacteria From Patients With Celiac Disease and Healthy Subjects Distinctly Affect Gluten Breakdown and Immunogenicity. Gastroenterology. 2016;151(4):670-83.

125. Herran AR, Perez-Andres J, Caminero A, Nistal E, Vivas S, Ruiz de Morales JM, et al. Gluten-degrading bacteria are present in the human small intestine of healthy volunteers and celiac patients. Res Microbiol. 2017;168(7):673-84.

126. Allen KJ, Koplin JJ, Ponsonby AL, Gurrin LC, Wake M, Vuillermin $P$, et al. Vitamin D insufficiency is associated with challengeproven food allergy in infants. J Allergy Clin Immunol. 2013;131(4):1109-16, 16 e1-6.

127. Mullins RJ, Camargo CA. Latitude, sunlight, vitamin D, and childhood food allergy/anaphylaxis. Curr Allergy Asthma Rep. 2012;12(1):64-71.

128. Rosendahl J, Fogelholm M, Pelkonen A, Makela MJ, Makitie O, and Erkkola M. A History of Cow's Milk Allergy Is Associated with Lower Vitamin D Status in Schoolchildren. Horm Res Paediatr. 2017;88(3-4):244-50.

129. Matsui T, Yamashita H, Saneyasu KI, Tanaka H, Ito K, Inagaki N. Vitamin D deficiency exacerbates sensitization and allergic diarrhea in a murine food allergy model. Allergol Int. 2018;67(2):289-91

130. Wu J, Zhong Y, Shen X, Yang K, Cai W. Maternal and earlylife vitamin $D$ deficiency enhances allergic reaction in an ovalbumin-sensitized BALB/c mouse model. Food Nutr Res. 2018;62

131. James J, Weaver V, Cantorna MT. Control of Circulating IgE by the Vitamin D Receptor In Vivo Involves B Cell Intrinsic and Extrinsic Mechanisms. J Immunol. 2017;198(3):1164-71.

132. Turfkruyer $M$, Rekima $A$, Macchiaverni $P$, Le Bourhis L, Muncan $V$, van den Brink $G R$, et al. Oral tolerance is inefficient in neonatal mice due to a physiological vitamin A deficiency. Mucosal Immunol. 2016;9(2):479-91.

133. Kunisawa J, Arita M, Hayasaka T, Harada $T$, Iwamoto $R$, Nagasawa R, et al. Dietary omega3 fatty acid exerts anti-allergic effect through the conversion to 17,18-epoxyeicosatetraenoic acid in the gut. Sci Rep. 2015;5:9750.

134. van den Elsen LW, Meulenbroek LA, van Esch BC, Hofman GA, Boon L, Garssen J, et al. CD25+ regulatory T cells transfer n-3 long chain polyunsaturated fatty acids-induced tolerance in mice allergic to cow's milk protein. Allergy. 2013;68(12):1562-70.

135. Foiles AM, Kerling EH, Wick JA, Scalabrin DM, Colombo J, Carlson SE. Formula with long-chain polyunsaturated fatty acids reduces incidence of allergy in early childhood. Pediatr Allergy Immunol. 2016;27(2):156-61.

136. van den Elsen LW, van Esch BC, Dingjan GM, Hofman GA, Garssen J, Willemsen LE. Increased intake of vegetable oil rich in n-6 PUFA enhances allergic symptoms and prevents oral tolerance induction in whey-allergic mice. $\mathrm{Br} \mathrm{J}$ Nutr. 2015;114(4):577-85.
137. Bae MJ, Shin HS, See HJ, Jung SY, Kwon DA, Shon DH. Baicalein induces CD4(+)Foxp3(+) T cells and enhances intestinal barrier function in a mouse model of food allergy. Sci Rep. 2016;6:32225.

138. Okada Y, Oh-oka K, Nakamura Y, Ishimaru K, Matsuoka S, Okumura K, et al. Dietary resveratrol prevents the development of food allergy in mice. PLoS One. 2012;7(9):e44338.

139. Yan X, Yan J, Huang K, Pan T, Xu Z, Lu H. Protective effect of baicalin on the small intestine in rats with food allergy. Life Sci. 2017;191:111-4.

140. Burks AW, Jones SM, Wood RA, Fleischer DM, Sicherer SH, Lindblad RW, et al. Oral immunotherapy for treatment of egg allergy in children. N Engl J Med. 2012;367(3):233-43.

141. Caminiti L, Pajno GB, Crisafulli G, Chiera F, Collura M, Panasci $G$, et al. Oral Immunotherapy for Egg Allergy: A Double-Blind Placebo-Controlled Study, with Postdesensitization Follow-Up. J Allergy Clin Immunol Pract. 2015;3(4):532-9.

142. Jones SM, Burks AW, Keet C, Vickery BP, Scurlock AM, Wood RA, et al. Long-term treatment with egg oral immunotherapy enhances sustained unresponsiveness that persists after cessation of therapy. J Allergy Clin Immunol. 2016;137(4):1117-27 e1-10.

143. Narisety SD, Frischmeyer-Guerrerio PA, Keet CA, Gorelik $M$, Schroeder J, Hamilton $R G$, et al. A randomized, doubleblind, placebo-controlled pilot study of sublingual versus oral immunotherapy for the treatment of peanut allergy. J Allergy Clin Immunol. 2015;135(5):1275-82 e1-6.

144. Nucera E, Ricci AG, Rizzi A, Mezzacappa S, Rienzo AD, Pecora $V$, et al. Specific oral immunotherapy in food allergic patients: transient or persistent tolerance? Postepy Dermatol Alergol. 2018;35(4):392-6.

145. Vickery BP, Scurlock AM, Kulis M, Steele PH, Kamilaris J, Berglund JP, et al. Sustained unresponsiveness to peanut in subjects who have completed peanut oral immunotherapy. J Allergy Clin Immunol. 2014;133(2):468-75.

146. Buchanan AD, Green TD, Jones SM, Scurlock AM, Christie L, Althage $K A$, et al. Egg oral immunotherapy in nonanaphylactic children with egg allergy. J Allergy Clin Immunol. 2007;119(1):199-205.

147. Burks AW, Jones SM, Wood RA, Fleischer DM, Sicherer SH, Lindblad RW, et al. Oral immunotherapy for treatment of egg allergy in children. N Engl J Med. 2012;367(3):233-43.

148. Jones SM, Pons L, Roberts JL, Scurlock AM, Perry TT, Kulis M, et al. Clinical efficacy and immune regulation with peanut oral immunotherapy. J Allergy Clin Immunol. 2009;124(2):292300, e1-97.

149. Sugimoto M, Kamemura N, Nagao M, Irahara M, Kagami S, Fujisawa $T$, et al. Differential response in allergen-specific $\lg E, \lg G s$, and $\lg A$ levels for predicting outcome of oral immunotherapy. Pediatr Allergy Immunol. 2016;27(3):276-82.

150. Varshney $P$, Jones SM, Scurlock AM, Perry TT, Kemper A, Steele $P$, et al. A randomized controlled study of peanut oral immunotherapy: clinical desensitization and modulation of the allergic response. J Allergy Clin Immunol. 2011;127(3):654-60.

151. Burton OT, Logsdon SL, Zhou JS, Medina-Tamayo J, AbdelGadir A, Noval Rivas M, et al. Oral immunotherapy induces IgG antibodies that act through FcgammaRIlb to suppress IgE-mediated hypersensitivity. J Allergy Clin Immunol. 2014;134(6):1310-7 e6. 
152. Gorelik M, Narisety SD, Guerrerio AL, Chichester KL, Keet CA, Bieneman AP, et al. Suppression of the immunologic response to peanut during immunotherapy is often transient. J Allergy Clin Immunol. 2015;135(5):1283-92.

153. Keet CA, Frischmeyer-Guerrerio PA, Thyagarajan A, Schroeder JT, Hamilton RG, Boden $S$, et al. The safety and efficacy of sublingual and oral immunotherapy for milk allergy. J Allergy Clin Immunol. 2012;129(2):448-55, 55 e1-5.

154. Syed A, Garcia MA, Lyu SC, Bucayu R, Kohli A, Ishida S, et al. Peanut oral immunotherapy results in increased antigeninduced regulatory T-cell function and hypomethylation of forkhead box protein 3 (FOXP3). J Allergy Clin Immunol. 2014;133(2):500-10 e11.

155. Hoh RA, Joshi SA, Liu Y, Wang C, Roskin KM, Lee JY, et al. Single $B$-cell deconvolution of peanut-specific antibody responses in allergic patients. J Allergy Clin Immunol. 2016;137(1):157-67.

156. Vickery BP, Lin J, Kulis M, Fu Z, Steele PH, Jones SM, et al. Peanut oral immunotherapy modifies $\lg E$ and $\lg G 4$ responses to major peanut allergens. J Allergy Clin Immunol. 2013;131(1):128-34 e1-3.

157. Patil SU, Ogunniyi AO, Calatroni A, Tadigotla VR, Ruiter B, Ma $A$, et al. Peanut oral immunotherapy transiently expands circulating Ara h 2-specific B cells with a homologous repertoire in unrelated subjects. J Allergy Clin Immunol. 2015;136(1):125-34 e12.
158. Bedoret $D$, Singh AK, Shaw V, Hoyte EG, Hamilton R, DeKruyff $\mathrm{RH}$, et al. Changes in antigen-specific T-cell number and function during oral desensitization in cow's milk allergy enabled with omalizumab. Mucosal Immunol. 2012;5(3):26776.

159. Ryan JF, Hovde R, Glanville J, Lyu SC, Ji X, Gupta S, et al. Successful immunotherapy induces previously unidentified allergen-specific CD4+ T-cell subsets. Proc Natl Acad Sci U S A. 2016;113(9):E1286-95.

160. Abdel-Gadir A, Schneider L, Casini A, Charbonnier LM, Little SV, Harrington T, et al. Oral immunotherapy with omalizumab reverses the Th2 cell-like programme of regulatory $T$ cells and restores their function. Clin Exp Allergy. 2018;48(7):825-36.

\section{- Leticia Tordesillas}

Department of Tumor Biology

H. Lee Moffitt Cancer Center 12902 USF Magnolia Drive

Tampa, FL, USA 33612

E-mail: leticia.tordesillas@moffitt.org 